\title{
Anotações para um balanço do Programa de Pós-graduação em Arquitetura e Urbanismo
}

\author{
Sarah Feldman \\ Arquiteta, professora doutora, coordenadora do Programa de \\ Pós-graduação em Arquitetura e Urbanismo do Departamento de \\ Arquitetura e Urbanismo da EESC-USP, Av. Trabalhador \\ Sancarlense, 400, CEP 13566-590, São Carlos, SP, (16) 3373- \\ 9303, sarahfel@sc.usp.br
}

demarcação de um campo preciso de ensino e pesquisa em nível de pós-graduação abrangendo teoria e história da arquitetura e do urbanismo e a interface entre tecnologia, arquitetura e urbanismo vem se construindo ao longo dos 30 anos de atividades do Programa de Pós-graduação em Arquitetura e Urbanismo da Escola de Engenharia de São Carlos da Universidade de São Paulo. Nessa trajetória podem se distinguir diferentes momentos que revelam particularidades de interlocução entre arquitetura e engenharia, na medida em que o Programa está inserido numa escola de engenharia.

Criado em 1970, por iniciativa do arquiteto e professor Paulo de Camargo e Almeida, o Curso de Mestrado em Arquitetura visava a contribuir para o desenvolvimento da industrialização da construção, considerada naquele momento instrumento fundamental para solução do déficit de habitações populares do País. Este perfil inicial foi, no entanto, se desvirtuando, e a ênfase do curso se direcionou para duas linhas de pesquisa: "Arquitetura e Construção" e "Arquitetura e Comunicação". Estas, até meados dos anos 1980, continuaram reafirmando o predomínio das questões relativas à construção em detrimento daquelas relativas à arquitetura, em função das áreas de especialização e de interesse de pesquisa de professores de uma escola de engenharia.

É a partir de 1985, com a implantação de um curso de graduação em arquitetura e urbanismo, que se inicia um processo de reestruturação conceitual do Departamento - então denominado "de Arquitetura e Planejamento" - que terá repercussões sobre a Pós-graduação. Com a criação do novo curso de graduação, novos professores foram contratados, em sua maioria arquitetos. Em 1984, nove dos 14 docentes eram engenheiros e cinco eram arquitetos. Em 1989, quando se completa o quadro para os cinco anos de graduação, dobra o número de docentes, sendo mais da metade arquitetos, além de uma socióloga. A mudança no número e no perfil do corpo docente será determinante para configurar um programa voltado para o universo não só da arquitetura, mas também do urbanismo, e que dialogue com a engenharia.

Um primeiro movimento de ampliação de horizontes para além das questões construtivas do edifício se expressa no credenciamento do Curso de Pósgraduação com a área de concentração em Tecnologia do Ambiente Construído, em 1989. No início dos anos 1990, catalisando o potencial de um quadro de docentes consolidado, teve início a discussão para implantação de uma área voltada para o ensino e para a pesquisa de teoria e história da arquitetura e do urbanismo. Em 1993, o Programa passa a se estruturar em duas áreas: Arquitetura e Tecnologia (hoje denominada Arquitetura, Urbanismo e Tecnologia), que resultou da reorganização das linhas de pesquisa dominantes no período anterior, e uma nova área, Teoria e História da Arquitetura e do Urbanismo. Desse momento até 2003, quando o Programa inicia o curso de Doutorado, um conjunto de linhas de pesquisa se consolida. O Departamento, que passou a se denominar "de Arquitetura e Urbanismo", conta hoje com 34 docentes, sendo 25 arquitetos, 7 engenheiros, uma socióloga e uma física. Do conjunto de docentes, 25 estão credenciados na Pós-graduação, e, destes, sete são livre-docentes. 
O perfil dos alunos é marcado por duas tendências dominantes: docentes de faculdades de arquitetura e urbanismo públicas ou privadas e recémformados com experiência em investigação científica. Estes alunos vêm do interior paulista, de Estados vizinhos como Paraná, Minas Gerais, Goiás e Mato Grosso e das regiões Norte e Nordeste do País, assim como de universidades da América Latina. Estas duas tendências revelam que o Programa, cujos cursos de Mestrado e de Doutorado são os únicos de instituição pública no interior do Estado de São Paulo na área, vem, por um lado, atendendo a uma demanda gerada pela proliferação de cursos de graduação em arquitetura e urbanismo e pelas exigências de titulação de seus docentes impostas pelo MEC. Hoje são 167 cursos no Brasil, quase $50 \%$ na região Sudeste, em especial no Estado de São Paulo, onde estão instalados 51. Dos cursos de graduação paulistas, apenas quatro são de instituições públicas. Por outro lado, o Programa vem se consolidando na formação de jovens pesquisadores, principalmente no campo da Teoria e História da Arquitetura e do Urbanismo. Uma característica do Programa é a alta incidência de alunos em regime de dedicação exclusiva. Mais de $30 \%$ dos alunos têm bolsas de estudo das agências nacionais (CNPq e CAPES) e da FAPESP.

A produção da área de Teoria e História nos últimos dez anos corresponde a mais de $50 \%$ do total dos trabalhos concluídos. Em função disso, a área atingiu um patamar de consolidação que permite vislumbrar uma produção consistente em quatro vertentes. Em primeiro lugar, uma forte tendência em pesquisas sobre o modernismo arquitetônico e urbanístico brasileiros e latino-americanos, enfocando planos e projetos, suas concepções e filiações teórico-conceituais, seus compromissos sociais e estéticos. Em segundo lugar, trabalhos sobre as trajetórias profissionais de engenheiros, arquitetos e urbanistas, envolvendo sua inserção na vida cultural do País, suas relações com vertentes do movimento internacional e sua inserção na estruturação de um campo profissional. Em terceiro lugar, estudos abrangendo processos de estruturação e de transformação urbana, a partir de mudanças sociais, econômicas, culturais e tecnológicas, assim como pesquisas que desvendam processos de construção de instituições e de instrumentos de intervenção na cidade. E, finalmente, estudos no campo da habitação, que vêm sendo desenvolvidos a partir de múltiplos enfoques: das políticas e programas habitacionais, das mudanças dos modos de vida e do morar urbano, além de estudos voltados para habitação rural e assentamentos agroindustriais.

Na área de Arquitetura, Urbanismo e Tecnologia, algumas linhas de pesquisa já estabelecem uma interlocução com arquitetura, enquanto outras ainda desenvolvem pesquisas "aplicáveis" à arquitetura. No primeiro caso, destacam-se os trabalhos voltados ao desenvolvimento e avaliação de produtos e processos no ambiente construído e os trabalhos voltados à utilização de materiais e processos construtivos inovadores visando à sustentabilidade ambiental e econômica, e alguns trabalhos no campo do conforto ambiental já se voltam para obras de arquitetos específicos. A maioria desses trabalhos estabelecem este encontro nos estudos de habitação. A interlocução entre tecnologia e urbanismo permanece como um campo praticamente inexplorado, apenas com estudos relacionados às tecnologias de informação.

As dissertações concluídas, assim como as dissertações e teses em andamento, no Programa, têm seus objetos empíricos muito relacionados às origens geográficas dos alunos. Nesse sentido, os trabalhos das duas áreas vêm revelando a produção de arquitetos, engenheiros, urbanistas, assim como processos de desenvolvimento e de transformação urbana não apenas de diferentes capitais do País, como também de um grande número de cidades metropolitanas e não metropolitanas do interior paulista. Assim, a produção do Programa se caracteriza pela diversidade de realidades urbanas e culturais, o que vem configurando a construção da historiografia de territórios pouco explorados nas pesquisas da área.

Este e outros aspectos da produção dos últimos dez anos do Programa merecem uma análise coletiva e mais aprofundada para que se detectem potencialidades e lacunas do ponto de vista geográfico, temporal, temático e conceitual a serem incluídas em pesquisas e disciplinas. Mais do que isso, um balanço em profundidade sem dúvida colaborará para mais um momento de re-visão e re-flexão na trajetória do Programa. 